Cette création a pour but d'aider les Africains et les Européens qui ont des responsabilités dans l'évolution politique, économique et sociale des divers pays de l'Afrique subsaharienne à acquérir la formation nécessaire à l'accomplissement de leur tâche.

Le programme du Centre s'adresse à différentes catégories d'étudiants. D'abord aux futurs chercheurs, Européens et Africains, qui se destinent à une carrière scientifique professionnelle dans l'une ou l'autre des disciplines des sciences humaines en Afrique; ensuite à des personnes qu'une formation universitaire déterminée conduit en Afrique et qui souhaitent, dans leurs activités, être particulièrement attentives aux problèmes humains; enfin à des étudiants étrangers ayant déjà des qualifications dans une discipline humaine et qui désirent s'orienter vers une spécialisation africaine en Afrique même.

Le Centre, dont les cours, donnés par neuf professeurs, se répartissent en trois spécialisations - anthropologie physique, anthropologie sociale et linguistique - délivre des diplômes de licencié et de docteur en anthropologie africaine. Le diplôme de licencié en anthropologie africaine, groupe linguistique, est l'équivalent, pour les langues africaines, d'un diplôme de licencié en philologie romane ou germanique pour les langues d'Europe occidentale.

$\mathrm{La}$ licence est accessible aux porteurs de certains diplômes de candidature et de licence délivrés par l'Université officielle; en outre, le Centre peut admettre l'équivalence de diplômes universitaires belges ou étrangers.

Les études de licence durent deux ans, mais la présence effective à Élisabethville peut être réduite à deux semestres pour les porteurs d'un autre diplôme de licence. L'épreuve de doctorat, qui ne peut être tentée qu'une année au moins après l'obtention du diplôme de licencié en anthropologie africaine, comporte la soutenance d'une dissertation originale et d'une thèse annexe.

Toute personne qui désire des renseignements complémentaires sur les inscriptions, conditions d'admission, programmes, etc. est prié de s'adresser au président du C.I.A.L.A., Université officielle du Congo Belge et du Ruanda-Urundi, B.P. no ${ }^{\circ} 825$, Élisabethville.

\title{
The Northern Region Literature Agency, Nigeria
}

The Northern Region Literature Agency in Nigeria, popularly known as N.O.R.L.A., was founded in 1954 and is subsidized by the Northern Region Government. Its policy is controlled by the 'Fight Against Ignorance Committee', consisting of the Ministers of Finance, Education, and Internal Affairs, and Mr. A. J. Carpenter, M.B.E., formerly Federal Adviser on Adult Education, is its director. The publications of N.O.R.L.A. are distributed through agents, of whom there are 50 or 60 in each Province, on a commission basis, and today every important village has a bookshop selling newspapers, periodicals, and books published by N.O.R.L.A. and other organizations. There are today thirteen newspapers : six in Hausa, and one each in Tiv, Yoruba, Fulfulde, Kanuri, Nupe, Igala, and Idoma. A paper for the Niger is to be published by the Agency in the near future and an existing Kano paper taken over. Nearly 85,000 copies of these newspapers are sold every fortnight. N.O.R.L.A. also publishes two monthly magazines, The World and Agolfir, which are mainly educational; their Hausa publications include plays written by local authors and travel books.

\section{The Howard University Library's African Collection}

A catalogue has recently been published of the African Collection in the Moorland Foundation of the Howard University Library, Washington, D.C. The work of compilation has been carried out mainly by students in the Program of African Studies at Howard University under the editorship of Dorothy B. Porter. The materials listed in the present volume are those which had been received up to June 1957 . They include 4,865 book entries, arranged alphabetically by countries or other political units, which are in turn grouped under 